\title{
PENGARUH PEMANGKASAN DAUN BAGIAN BAWAH TERHADAP PRODUKSI JAGUNG MANIS (Zea mays var. saccharata Sturt)
}

\author{
Augus Y. M. Sumajow \\ Johannes E. X. Rogi \\ Selvie Tumbelaka
}

\begin{abstract}
The purpose of this study was to determine the effect of trimming the bottom leaves to the increased production of sweet corn crop. This research was arranged in a completely randomized design (CRD) with 4 treatments and repeated 5 times. Pruning is done at the age of 50 days after planting. The results obtained from this study are pruning significant effect on the rising corncob where the highest rates in the third pruning leaves the bottom (P3) weighing $333.04 \mathrm{~g}$. In the variable length cob, cut 3 pieces (P3) gives the most high, $21.25 \mathrm{~cm}$ while trimming treatment 1 piece $(P 1)$ and a second piece (P2) shows the results are not significantly different from each other but significantly different from that of the untreated $(P 0)$, While on the cob entire circumference of the variable level of treatment $(P 1, P 2, P 3)$ results are not significantly different from each other but all three significantly different from that of the untreated $(P 0)$ ddengan highest yield is in P3 which is $17.27 \mathrm{~cm}$. from these results it can be concluded that treatment of the bottom leaf pruning can increase the production of sweet corn.
\end{abstract}

\begin{abstract}
ABSTRAK
Tujuan penelitian ini adalah untuk mengetahui pengaruh pemangkasan daun bagian bawah terhadap peningkatan produksi tanaman jagung manis. Penelitian ini disusun dalam rancangan acak lengkap (RAL) dengan 4 Perlakuan dan diulang 5 kali. Pemangkasan dilakukan pada umur 50 hari sesudah tanam. Hasil yang diperoleh dari penelitian ini adalah Pemangkasan memberikan pengaruh nyata pada meningkatnya bobot tongkol dimana angka tertinggi pada pemangkasan 3 helai daun bagian bawah (P3) seberat 333,04 g. Pada variabel panjang tongkol, pemangkasan 3 helai (P3) memberikan hasil yang paling tinggi yakni $21,25 \mathrm{~cm}$ sedangkan perlakuan pemangkasan 1 helai (P1) dan 2 helai (P2) menunjukkan hasil tidak saling berbeda nyata tetapi berbeda nyata dengan tanpa perlakuan (P0). Sedangkan pada variabel lingkar tongkol seluruh taraf perlakuan (P1, P2, P3) memberikan hasil tidak saling berbeda nyata tetapi ketiganya berbeda nyata dengan tanpa perlakuan (P0) ddengan hasil tertinggi adalah pada P3 yakni $17,27 \mathrm{~cm}$. Dari hasil penelitian ini dapat disimpulkan bahwa perlakuan pemangkasan daun bagian bawah dapat meningkatkan produksi jagung manis.
\end{abstract}

Kata Kunci: Pemangkasan, Produksi, Daun Bagian bawah, Jagung manis

\section{PENDAHULUAN}

\section{Latar Belakang}

Jagung manis (Zea mays var. saccharata Sturt) adalah salah satu pangan alternatif pengganti nasi yang sangat di gemari masyarakat. Jenis jagung ini telah banyak dibudidayakan oleh petani jagung termasuk di Sulawesi Utara, dimana potensi hasilnya dapat mencapai $14-18$ ton/ha. Kondisi yang terjadi di tingkat petani belum mampu mencapai produktivitas yang diharapkan. Rendahnya produktivitas jagung ini disebabkan antara lain oleh: faktor eksternal seperti Penggunaan benih yang tidak terseleksi dengan baik, penyiapan 
lahan yang kurang optimal, jarak tanam yang tidak teratur, aplikasi pemupukan kurang tepat, hama penyakit dan gulma tidak dikendalikan dengan baik, (Runtunuwu, 1990). Dan faktor internal seperti distribusi asimilat yang terhambat oleh sifat parasit organ tanaman itu sendiri.

Untuk memperoleh pertumbuhan dan produksi yang diharapkan, perlu di lakukan upaya agar jumlah radiasi yang diterima tanaman maksimal. Salah satu cara yang dapat dilakukan adalah memodifikasi tanaman. Jagung adalah tanaman tipe $\mathrm{C}-4$ yang sangat membutuhkan penyinaran dengan intensitas cukup tinggi. Tanaman jagung juga dikenal efisien dalam penggunaan radiasi. Radiasi Matahari merupakan bahan baku esensial untuk pertumbuhan dan produksi tanaman. Besaran radiasi total harian yang diterima oleh permukaan bumi berkisar antara 4,0 - 30,0 $\mathrm{MJ} / \mathrm{m}^{2} / \mathrm{h}$. Nilai rataan didaerah tropis adalah 15 $\mathrm{MJ} / \mathrm{m}^{2} / \mathrm{h}$. Pada musim kemarau total radiasi dapat mencapai $20-25 \mathrm{MJ} / \mathrm{m}^{2} / \mathrm{h}$ sedangkan untuk musim penghujan adalah $5-10 \mathrm{MJ} / \mathrm{m}^{2} / \mathrm{h}$. Itulah jumlah energi yang tersedia bagi proses fotosintesis tanaman, (Paruntu, 1992).

Modifikasi tanaman dapat dilakukan dengan cara pemangkasan daun untuk memaksimalkan masuknya cahaya matahari ke dalam area pertanaman serta memperkecil selisih antara produksi asimilat dan penggunaannya oleh daun. Teknik pemangkasan sangat baik diterapkan pada jagung manis karena dengan pemangkasan daun bagian bawah dapat mengurangi jumlah daun yang tidak efektif menerima cahaya sehingga diharapkan akan meningkatkan produksi. Selain itu limbah daun hasil pemangkasan dapat dimanfaatkan untuk pakan ternak serta memudahkan dalam melakukan pengendalian gulma.

\section{Lingkungan Tumbuh dan Fase Pertumbuhan Tanaman Jagung}

Di Indonesia, Tanaman jagung dapat ditumbuhkan pada dataran rendah sampai pegunungan yang ketingginannya mencapai $1500 \mathrm{~m}$ dpl. Ketinggian optimum untuk pertumbuhan jagung adalah $0-600 \mathrm{~m} \mathrm{dpl}$, merupakan daerah terbuka, dengan curah hujan optimal adalah 100-200 mm/bulan (Fisher and Palmer, 1992) atau $500-1200 \mathrm{~mm} / \mathrm{masa}$ tumbuh yang terbagi atas: $100-295 \mathrm{~mm}$ pada bulan I, 150 - $310 \mathrm{~mm}$ pada bulan II dan III serta $100-295 \mathrm{~mm}$ pada bulan IV. Suhu optimum untuk perkecambahan jagung berkisar antara $18-21{ }^{\circ}$ C. Suhu optimum untuk pertumbuhan vegetatif siang hari adalah $30-35$ ${ }^{\circ} \mathrm{C}$ dan pada malam hari adalah $25{ }^{\circ} \mathrm{C}$. Pada suhu $40-44{ }^{\circ} \mathrm{C}$ embrio jagung akan rusak dan mati (Syarif, 1991). Selanjutnya Djaenuddin dkk (2003) mengemukakan bahwa tanaman jagung dapat tumbuh pada berbagai jenis tanah namun yang paling baik adalah pada tanah dengan aerasi dan drainase yang baik, bertekstur halus atau agak halus, memiliki kedalaman efektif $25->60 \mathrm{~cm}$, salinitas antara 2,5 - 5,9 ds/m, pH optimum 5,8 - 7,8 dengan kejenuhan basa $35->50 \%$ serta memiliki bahan organik cukup.

Selama periode pertumbuhan, tanaman jagung memerlukan radiasi yang cukup. Tanaman jagung tergolong tanaman $\mathrm{C} 4$ yang sangat efisien dalam pemanfaatan cahaya. Jumlah cahaya yang diterima selama fase berbunga merupakan faktor yang penting untuk penentuan jumlah biji (Paruntu dan Palenewen, 1990).

Seperti tanaman jagung pada umumnya, pertumbuhan jagung manis di bagi atas 3 fase utama yaitu: vegetatif, generatif dan penuaan. Stadia pertumbuhan sebelum keluar bunga betina (silking) dapat diidentifikasi dengan menghitung jumlah daun yang telah membuka sempurna, benih jagung yang di tanam pada tanah lembab dan panas akan muncul 4 - 5 hari setelah tanam dan pada kondisi terlalu dingin bisa beragam dari $4-15$ hari. Sedangkan stadia pertumbuhan setelah silking dapat diidentifikasi melalui perkembangan biji.

\section{Jenis dan Klasifikasi Jagung}

Berdasarkan tujuan penggunaan atau pemanfaatannya, komoditas jagung di Indonesia dibedakan atas jagung untuk bahan pangan, jagung untuk bahan industri pakan, jagung untuk bahan industri olahan, dan jagung untuk bahan tanaman atau disebut benih. Masingmasing jenis bahan tersebut memiliki nilai ekonomi yang berarti. Sebagai salah satu bahan pangan, dapat dikonsumsi langsung maupun perlu pengolahan seperti jagung rebus, bakar, maupun dimasak menjadi nasi. Sebagai bahan pakan ternak, biji pipilan kering digunakan untuk pakan ternak bukan ruminan seperti ayam, itik, puyuh, dan babi, sedangkan seluruh 
bagian tanaman (brangkasan) jagung atau limbah jagung, baik yang berupa tanaman jagung muda maupun jeraminya dimanfaatkan untuk pakan ternak ruminansia. Selain itu, jagung juga berpotensi sebagai bahan baku industri makanan, kimia farmasi dan industri lainnya yang mempunyai nilai tinggi, seperti tepung jagung, gritz jagung, minyak jagung, dextrin, gula, etanol, asam organik, dan bahan kimia lain. Disamping itu, bahan tanaman jagung yang umum disebut benih, merupakan bagian terpenting dalam suatu proses produksi jagung itu sendiri.

Plasma nutfah tanaman jagung yang tumbuh di dunia mempunyai banyak jenis. Para ahli botani dan pertanian mengklasifikasikan tanaman jagung berdasarkan sifat endosperma (kernel)

Berdasarkan penampilan dan tekstur biji (kernel), jagung diklasifikasikan ke dalam 7 tipe yaitu: flint corn, dent corn, sweet corn, pop corn, floury corn, waxy corn dan pod corn. Dari ketujuh jagung tersebut, jagung mutiara (flint corn) dan semi gigi kuda (dent corn), serta jagung manis (sweet corn) yang banyak dibudidayakan di Indonesia.

Jagung manis atau sweet corn adalah salah satu jenis jagung yang semakin populer dikonsumsi karena memiliki rasa yang lebih manis, aroma lebih harum serta kandungan gizi yang lebih tinggi dibandingkan jagung biasa (Tim penulis PS, 2001).

\section{Pemangkasan dan Pembagian Asimilat}

Pemangkasan dapat diartikan sebagai membuang atau memotong bagian tertentu dari suatu tanaman. Salah satu tujuan pemangkasan adalah untuk meningkatkan produktivitas. Tanaman jagung yang diusahakan saat ini umumnya memiliki tipe kanopi yang relatif horizontal terutama pada bagian tengah sampai ujung lembaran daun. Morfologi yang demikian akan menyebabkan saling menaungi (mutual shading) antar individu tanaman jika ditanam pada populasi yang tinggi dengan jarak tanam yang rapat, sehingga daun-daun bagian bawah menerima cahaya dengan jumlah yang sangat rendah. Akibatnya laju fotosintesis daun tersebut menjadi lebih rendah dibandingkan laju respirasi. Menurut Brown (1988), daun demikian di sebut parasit karena tidak dapat bertindak sebagai sumber (source) tetapi lebih berfungsi sebagai pengguna (sink). Jika jumlah daun parasit cukup banyak maka dapat menurunkan hasil tanaman, karena kompetisi antar bagian tanaman untuk memperoleh asimilat cukup tinggi. Pembagian asimilat biasanya di berikan ke daerah pemanfaatan dekat sumber, misalnya daun-daun sebelah atas pada dasarnya mengekspor ke puncak batang, daun-daun sebelah bawah ke akar dan daun bagian tengah ke keduanya (Gardner, dkk, 1985).

Menurut Allison dan Watson (1966), pemangkasan daun jagung dapat meningkatkan efisiensi daun-daun yang tertinggal. Pada tanaman serealia selama fase pengisian biji yang cepat, penghilangan beberapa daun akan meningkatkan laju fotosintesis daun-daun sisa apabila intensitas cahaya tinggi, Dan daun paling dekat dengan tongkol adalah yang memiliki peran paling aktif pada saat pengisian biji. Pemangkasan sebagian daun jagung saat masak susu (milking stage) meningkatkan hasil 3,5\% (Hanway, 1969).

Hasil penelitian dari Kadekoh (2002) menyatakan bahwa pemangkasan jagung pada umur 21 hari setelah tasseling menghasilkan biji lebih banyak dan berbeda lebih besar di bandingkan dengan pemangkasan $7-14$ hari setelah tasseling. Sedangkan menurut Hosang (1991) pemangkasan 2 helai diatas tongkol pada umur 18 hari setelah keluar bunga betina pada varietas kalingga menaikkan hasil biji kering di bandingkan dengan tanpa pemangkasan.

Penelitian tentang pengaruh pemangkasan beserta kombinasinya terhadap pertumbuhan, perkembangan dan produktivitas tanaman telah banyak dilakukan, akan tetapi belum banyak informasi yang tersedia tentang bagaimana jika pemangkasan dilakukan terhadap daun jagung yang ada di bagian bawah atau yang lebih dekat dengan permukaan tanah.

Berdasarkan pertimbangan inilah maka di anggap perlu dilakukan penelitian tentang pengaruh pemangkasan daun bagian bawah terhadap produksi tanaman jagung manis.

\section{Rumusan Masalah}

Dari uraian yang menjadi latar belakang, maka dapat dirumuskan masalah bahwa produksi jagung manis masih rendah sehingga perlu di tingkatkan. Upaya peningkatan produksi dapat dilakukan dengan berbagai cara diantaranya dengan memodifikasi tanaman lewat pemangkasan. Berdasarkan 
pemikiran inilah maka rumusan masalah yang akan di kemukakan dalam penelitian ini adalah: Apakah pemangkasan daun bagian bawah pada jagung manis dapat meningkatkan produksi?

\section{Tujuan}

Adapun yang menjadi tujuan penelitian ini adalah untuk mengetahui pengaruh pemangkasan daun bagian bawah terhadap peningkatan produksi tanaman jagung manis.

\section{Manfaat Penelitian}

Manfaat dari penelitian ini adalah untuk memberikan informasi mengenai pengaruh pemangkasan daun bagian bawah terhadap peningkatan produksi tanaman jagung manis.

\section{METODOLOGI PENELITIAN}

Penelitian ini dilaksanakan di Desa Lopana Kecamatan Amurang Timur dengan waktu pelaksanaan selama 3 bulan (Oktober 2011 s/d Januari 2012) mulai dari persiapan sampai panen dan pengambilan data pada setiap variabel yang di amati. Penanaman dilakukan pada 11 November 2011.

\section{Bahan Dan Alat}

Bahan yang digunakan: benih jagung manis hibrida varietas Bonanza F1, Pupuk Urea, NPK, Pestisida Furadan 4G.

Alat-alat yang digunakan: Traktor, cangkul, sekop, meteran, tali, timbangan analitik, Timbangan biasa, label, tugal, gunting, pisau, bamboo, ember, plastik dan alat tulis menulis, Kamera.

\section{Metode Penelitian}

Penelitian ini di lakukan dalam bentuk percobaan penanaman jagung di lapangan sampai panen, menggunakan Rancangan Acak Lengkap dengan 4 Perlakuan yaitu:

1. Tanpa Pemangkasan (0\%) sebagai kontrol, (P0)

2. Pemangkasan 1 Helai daun bagian bawah (P1)

3. Pemangkasan 2 Helai daun bagian bawah (P2)

4. Pemangkasan 3 Helai daun bagian bawah (P3)

dengan pengulangan sebanyak 5 kali sehingga di peroleh 20 satuan percobaan.

\section{Prosedur Kerja}

1. Pemilihan varietas jagung manis hibrida yakni menggunakan varietas Bonanza F1.

2. Penyiapan lahan dan pengolahan tanah, dilakukan dengan menggunakan traktor roda 4 dengan cara pembajakan 1 (satu) kali dan di lakukan penyisiran sebanyak 2 (dua) kali. Selanjutnya di lakukan pembuatan petak percobaan. Dengan ukuran 6 meter X 1,75 meter, dengan jarak antar petak 1 meter.

3. Benih ditanam dengan jarak tanam $70 \times 25$ $\mathrm{cm}$, dengan kedalaman $\pm 3-5 \mathrm{~cm}$. Penanaman dilakukan tanggal 11 November 2011

4. Pemupukan dilakukan sesuai anjuran pemupukan untuk jagung dengan aplikasi pemupukan sebanyak 3 kali yakni pemupukan dasar dilakukan saat penanaman yakni Urea $100 \mathrm{~kg} / \mathrm{ha}$, NPK $50 \mathrm{~kg} / \mathrm{ha}$. Pemupukan susulan I dilakukan saat penyiangan I dan pemupukan susulan II dilakukan saat penyiangan II dengan dosis yang sama.

5. Penyulaman dilakukan pada saat umur 7 hari sesudah tanam.

6. Pemangkasan dilakukan secara serentak pada umur 50 hari sesudah tanam atau setelah daun terakhir terbentuk sempurna, sesuai dengan perlakuan.

7. Panen dilakukan pada umur 65 hari sesudah tanam.

\section{Pengambilan Data}

Pengambilam data dilakukan pada saat panen dengan mengambil 50\% jumlah tanaman sampel diluar tanaman pinggir pada masing-masing blok seluruh klobot pada tongkol sampel dikupas sehingga yang tertinggal hanyalah tongkol dan biji jagung. Selanjutnya dilakukan pengukuran untuk setiap variabel yakni bobot tongkol menggunakan timbangan dan untuk panjang dan lingkar tongkol diukur menggunakan meteran.

\section{Analisis Data}

Data yang diperoleh pada setiap variable di analisa menggunakan analisis sidik ragam dan dilanjutkan dengan uji beda nyata terkecil (BNT).

\section{HASIL DAN PEMBAHASAN}

\section{Lingkar Tongkol Jagung Manis}

Lingkar tongkol jagung manis dipengaruhi oleh pemangkasan daun. Hal ini terlihat pada hasil sidik ragam. Hasil uji beda rata-rata (BNT 5\%) tertera pada Tabel 1. 
Lingkar tongkol jagung manis terbesar diperoleh pada perlakuan pemangkasan 3 helai daun bagian bawah (P3) yang tidak berbeda nyata dengan perlakuan pemangkasan 2 helai daun (P2) dan 1 helai daun (P1), tetapi berbeda nyata dengan tanpa pemangkasan (Tabel 1).

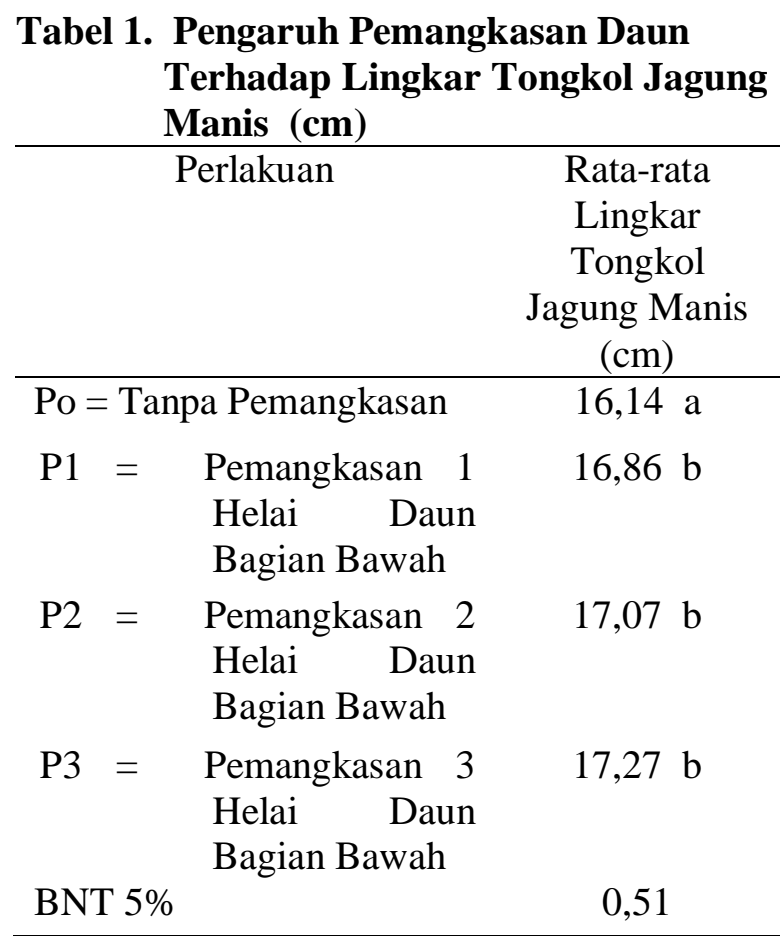

Keterangan : Angka yang diikuti dengan huruf yang sama, tidak berbeda nyata berdasarkan uji BNT 5\%.

\section{Panjang Tongkol Jagung Manis}

Hasil sidik ragam menunjukkan bahwa panjang tongkol jagung manis dipengaruhi oleh pemangkasan daun. Hasil uji beda rata-rata (BNT 5\%) pada Tabel 2.

Pemangkasan 3 helai daun bagian bawah memberikan tongkol terpanjang yang berbeda nyata dengan pemangkasan 2 helai daun bagian bawah (P2) dan pemangkasan 1 helai daun (P1) dan tanpa pemangkasan daun (Po). Pemangkasan 1 helai daun bagian bawah dan pemangkasan 2 helai tidak berbeda terhadap panjang tongkol jagung mnais. Tongkol terpendek pada perlakuan tanpa pemangkasan daun yang berbeda nyata dengan perlakuan pemangkasan lainnya (Tabel 2).

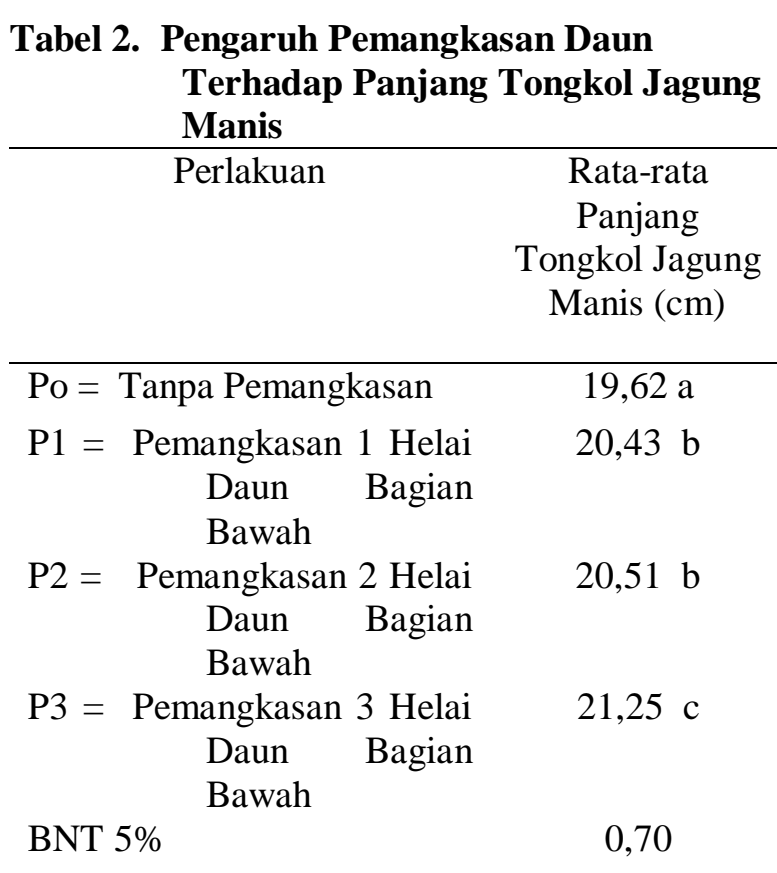

Keterangan : Angka yang diikuti dengan huruf yang sama, tidak berbeda nyata berdasarkan uji BNT $5 \%$.

\section{Bobot Tongkol Jagung Manis}

Hasil sidik ragam diperoleh bahwa bobot tongkol jagung manis dipengaruhi oleh pemangkasan daun. Hasil uji beda rata-rata (BNT 5\%) disajikan pada Tabel 3.

Pemangkasan 3 helai daun bagian bawah memberikan bobot tongkol paling tertinggi yang berbeda nyata dengan pemangkasan 2 helai daun bagian bawah (P2), pemangkasan 1 helai daun (P1) dan tanpa pemangkasan daun (Po). Pemangkasan 1 helai daun bagian bawah dan pemangkasan 2 helai tidak berbeda terhadap berat tongkol jagung Manis. Perlakuan tanpa pemangkasan daun memberikan tongkol paling ringan yang berbeda nyata dengan perlakuan lainnya (Tabel 3). Tujuan pemangkasan secara umum adalah untuk mengendalikan ukuran, mengatur keragaan tanaman serta mening-katkan produksi dan mutu tanaman (Harjadi, 1989).

Pemangkasan daun yang dilakukan pada umur 50 hari setelah tanam, menurut McWilliams dkk. 1999 dalam Surbekti, Syafruddin, Effendi, dan Sunarti (2012), pada umur tanaman tersebut tanaman jagung memasuki fase V11- Vn (jumlah daun terbuka sempurna 11 sampai daun terakhir 15-18). Fase ini berlangsung pada saat tanaman berumur antara 33 - 50 hari setelah berkecambah. 
Tabel 3. Pengaruh Pemangkasan Terhadap bobot Tongkol Jagung Manis (g)

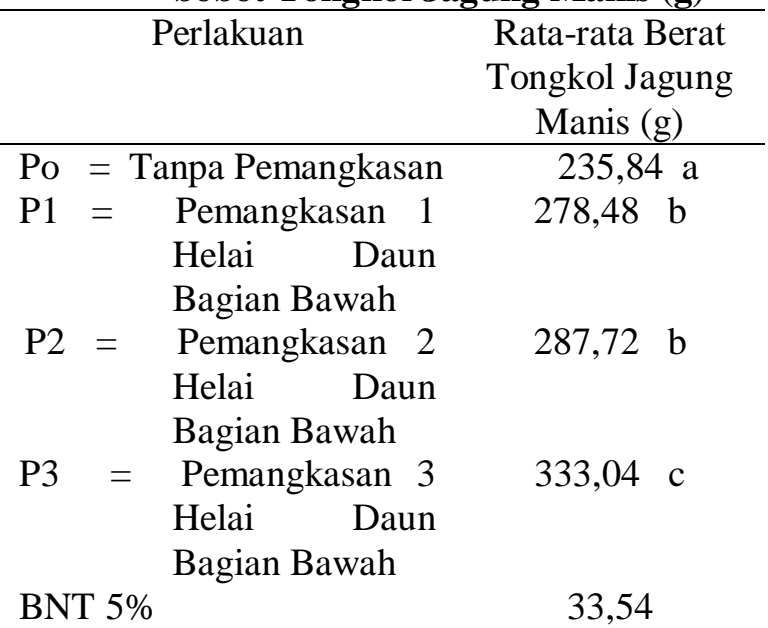

Keterangan : Angka yang diikuti dengan huruf yang sama, tidak berbeda nyata berdasarkan uji BNT $5 \%$.

Pada fase ini tanaman tumbuh dengan cepat dan akumulasi bahan kering meningkat dengan cepat pula. Kebutuhan hara dan air relatif sangat tinggi untuk mendukung laju pertumbuhan tanaman. Selanjutnya dikemukakan bahwa pada fase ini, kekeringan dan kekurangan hara sangat berpengaruh terhadap pertumbuhan dan perkembangan tongkol, dan bahkan akan menurunkan jumlah biji dalam satu tongkol karena mengecilnya tongkol, yang akibatnya menurunkan hasil. Kekeringan pada fase ini juga akan mem-perlambat munculnya bunga betina (silking). Setelah fase V11 - Vn, tanaman jagung memasuki fase Tasseling (berbunga jantan). Fase tasseling biasanya berkisar antara 45-52 hari, ditandai oleh adanya cabang terakhir dari bunga jantan sebelum kemunculan bunga betina (silk/rambut tongkol). Tahap VT dimulai 2-3 hari sebelum rambut tongkol muncul, di mana pada periode ini tinggi tanaman hampir mencapai maksimum dan mulai menyebarkan serbuk sari (pollen). Pada fase ini dihasilkan biomas maksimum dari bagian vegetatif tanaman, yaitu sekitar 50\% dari total bobot kering tanaman, penyerapan $\mathrm{N}, \mathrm{P}$, dan $\mathrm{K}$ oleh tanaman masingmasing 60-70\%, 50\%, dan 80-90\%. Pada penelitian ini tanaman jagung manis yang diberi pupuk sesuai dosis rekomendasi sehingga pada umur 50 hari tanaman dilakukan pemang-kasan tanaman tidak kekurangan hara. Menurut Sutejo (1995), tanaman membutuhkan unsur hara untuk pertumbuhan, perkembangan dan produksinya dalam jumlah yang optimal. Kemampuan tanaman untuk tumbuh dan berkembang secara optimal saat pertumbuhan vegetatif menjadi salah satu indikator keberhasilan dalam menunjukkan potensi produksinya.

Pemangkasan daun pada umur 50 hari setelah tanam jagung manis merupakan waktu yang tepat agar distribusi asimilat dapat lebih terkonsentrasi ke bagian tongkol, dan tidak lagi terbagi ke organ-organ lain. Hal ini diduga pada umur tanamn 50 hari setelah tanam daun-daun yang berada di bawah tongkol dianggap tidak lagi optimal dalam melakukan aktivitas fotosintesis sehingga perlu dilakukan pema-ngkasan. Pemangkasan pada 50 hari setelah tanam jagung manis dianggap sangat tepat karena pertumbuhan vegetatif telah berkurang dan distribusi asimilat digunakan untuk perkembangan tongkol jagung manis. Perlakuan tanpa pemangkasan menyebabkan terjadinya persaingan daun dengan organ lainnya dalam menggunakan asimilat, sedangkan aktivitasnya dalam melakukan fotosintesis tidak optimal lagi sehingga daun tersebut cenderung bersifat parasit.

Pemangkasan daun bagian bawah guna efisiensi penggunaan cahaya matahari menyebabkan hasil tanaman (lingkar tongkol, panjang tongkol, dan berat tongkol) meningkat dibandingkan dengan tanpa pemangkasan. (Gambar 1, 2, dan 3).

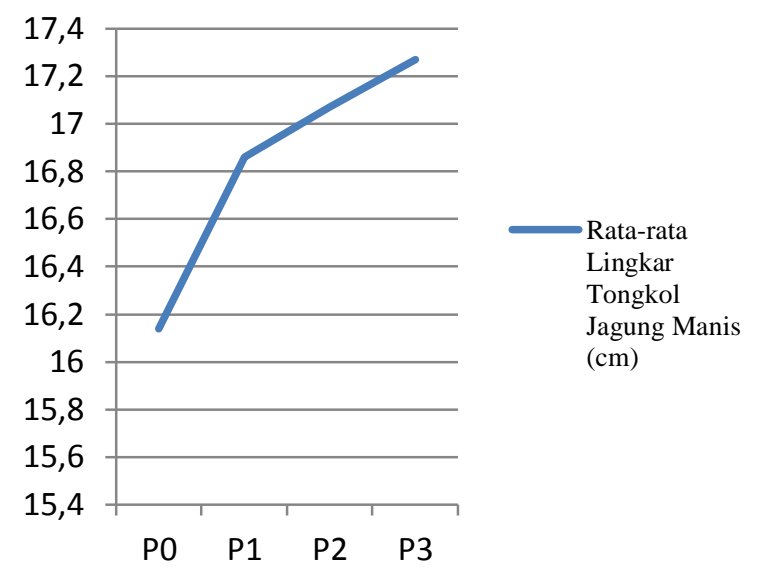

Gambar 1. Grafik Lingkar Tongkol Jagung Manis

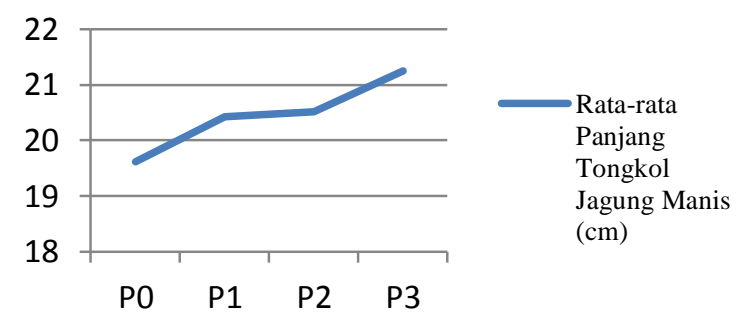

Gambar 2. Grafik Panjang Tongkol Jagung Manis 


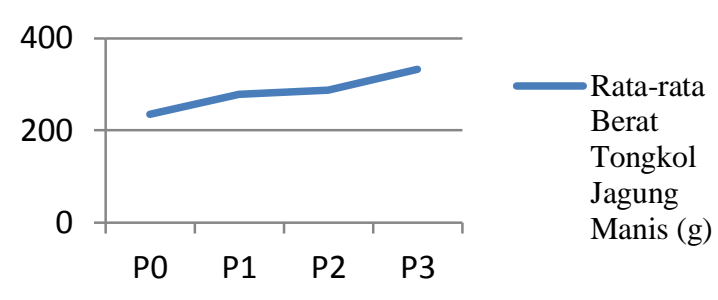

Gambar 3. Grafik bobot Tongkol Jagung Manis

Pemangkasan daun bagian bawah, memberikan kondicsi lingkungan yang baik untuk pertumbuhan tanaman jagung manis. Kondisi lingkungan tersebut menyangkut efisiensi pemanfaatan radiasi matahari, sehingga hasil fotosintesis lebih meningkat dan distribusi ke bagian tongkol juga lebih besar pada akhirnya meningkatkan lingkar, panjang, dan bobot tongkol.

Gambar 1, 2, dan 3 dapat dijelaskan bahwa semakin besar lingkar tongkol dan semakin panjang tongkol meningkatkan berat tongkol jagung manis. Hal ini disebabkan karena biji-biji yang berada dalam satu tongkol juga berkompetisi dalam menggunakan asimilat. Pertumbuhan lingkar tongkol dan panjang tongkol juga sangat tergantung pada suplai hara. Kebutuhan hara untuk pembentukan tongkol yang cukup tersedia, menyebabkan pertumbuhan tongkol akan mencapai pertumbuhan optimal. Dwidjoseputra (1980), menyatakan bahwa asimilasi yang diproduksi oleh daun akan didistribusikan ke seluruh bagian tanaman yang membutuhkannya.

Tanaman jagung manis yang tidak dipangkas daunnya, memiliki lingkar tongkol, panjang tongkol, jumlah baris biji, jumlah butir per baris, dan bobot tongkol lebih rendah dibandingkan dengan tanaman jagung manis yang mengalami pemangkasan daun bagian bawah. Hal ini diduga karena fotosintat yang dihasilkan pada waktu fase vegetatif, selain digunakan untuk perkembangan biji juga digunakan untuk organ tanaman yang tidak dipangkas, sehingga terjadi kompetisi di dalam tubuh tanaman itu sendiri. Jumlah baris biji per tongkol dan jumlah biji per baris paling rendah pada tanaman jagung manis yang tidak dilakukan pemangkasan. Menurut Harjadi (1980) bahwa laju asmilasi pada daun tua dan daun yang terdapat di bagian bawah adalah lebih rendah dibandingkan dengan daun muda atau daun yang di bagian atas dari tanaman jagung manis.

Jones dan Simmons (1983), bahwa berkurangnya suplai asimilat yang terjadi sebelum dan sampai awal perkembangan biji jagung menyebabkan terganggunya pembesaran sel embrio dan Endosperm. Pertumbuhan vegetatif tanaman jagung sangat mendukung pertumbuhan generatifnya, karena asimilat yang dihasilkan selama fase vegetatif akan disimpan dibagian organ tanaman yang lain sebelum organ generatifnya berkembang. Semakin banyak asimilat yang disimpan maka diharapkan semakin banyak pula asimilat itu ditransfer ke bagian tanaman yang membutuhkan pada waktu pertumbuhan generatif. Pada umur 50 hari setelah tanam daun bagian bawah sudah berubah fungsi dari produsen asimilat menjadi konsumen asimilat. Dengan pemangkasan maka daun tersebut tidak lagi mengambil hasil fotosintesis sehingga hasil fotosintesis tersebut dapat lebih dioptimalkan ke pengisian tongkol. Peaslee dalam Gardner dkk., (1991), mengukur laju fotosintesis pada tanaman jagung dimana laju fotosintesis yang rendah pada daun-daun yang lebih bawah. Laju fotosintesis yang rendah ini dihubungkan dengan adanya kandungan kalium, fosfor, magnesium dan nitrogen. Tampaknya apabila nutrien ini dalam persediaan terbatas, nutrien ini ditranslokasikan dari daun tua ke daun yang lebih muda yang menyebabkan makin cepatnya proses penuaan pada daun-daun sebelah bawah. Bustamam (2004) mengemukakan bahwa 25\% daun pada bagian atas memainkan peran penting dalam Pembentukan tongkol dan pengisian biji.

\section{KESIMPULAN DAN SARAN}

\section{Kesimpulan}

Dari Penelitian ini dapat disimpulkan bahwa pemangkasan daun bagian bawah memberikan pengaruh terhadap produksi jagung manis dimana Pemangkasan daun memberikan berpengaruh pada lingkar tongkol, panjang tongkol, bobot tongkol, jumlah baris bii per tongkol, dan jumlah biji per baris sehingga secara keseluruhan meningkatkan produksi jagung manis.

\section{Saran}

Perlu dilakukan penelitian pe-ngaruh pemangkasan daun dengan kombinasi dan waktu pemupukan pada tanaman jagung manis.

\section{DAFTAR PUSTAKA}

Allison J.G.S., and D.J. Watson. 1966. The Production and Distribution of Dry Matter in Maize After Flowering. Ann. Bot. 30:365-381. 
Brown, R.H., 1988. Growth of The Green Plant. P. 153-174. In M.B. Tesar (ed.) Physiological Basis of Crop Growth and Development. ASA,CSSA, Madison, WI

Bustamam, T. 2004. Pengaruh Posisi Daun Jagung Pada Batang Terhadap Pengisian dan Mutu Benih (Effects of Corn Leaf Position on The Stem on Seed Filling and Seed Quality). Stigma Volume XII No.2, April -Juni 2004

Djaenudin dkk., 2003. Petunjuk Teknis Evaluasi Lahan Untuk Komoditas Pertanian. Edisi Pertama. Balai Penelitian Tanah, Puslitbagtanak. Badan Penelitian dan Pengembangan Pertanian Bogor.

Dwijoseputro. D.1980. Pengantar Fisiologi Tumbuhan. PT. Gra-media, Jakarta.

Fisher, K.S. dan A.F.E. Palmer, 1992. Jagung Tropik. Terjemahan Tohari dan Soedharoedjian. Gadjah Mada University Press.

Fitter, A.H and R.K.M. Hay. 1991. Fisiologi Lingkungan Tanaman, Diterjemahkan oleh Sri Andani dan E.D. Purbayanti. Editor B.Sri Gandono. Gadjah Mada University Press. Yogyakarta.

Gardner, et all., 1985. Physiology of Corp Plants. Iowa State University Press. Ames. IA.

Gardner.,F.P.,R.B. Pierce dan R.L. Mitchell. 1991. Fisiologi Tanaman Budidaya, Terjemahan Herawati Susilo. Universitas Indonesia. Jakarta. 428 hal.

Goldsworthy, P.R., and N.M Fisher. 1992. The Physiology Of Tropical Field Crops (Fisiologi Tanaman Budidaya Tropik, Terjemahan Tohari). Penerbit Gadjah Mada University Press, Yogyakarta. penerbit Universitas Indonesia, Jakar-ta. 428 hal.

Hanway, J.J. 1971. How A Corn Plant Develops. Spesial Report No. 48. Iowa State University of Science and Technology Cooperative Extension Services, Ames, Iowa.

Harjadi, S.S. 1980. Pengantar Agronomi. PT. Gramedia, Jakarta.

Hidema J, Makino A, Kurita Y, Mae T, and Ohjima K. 1992. Changes in the level of chlorophyll and light-harvesting chlorophyl $\mathrm{a} / \mathrm{b}$ protein of PS II in rice leaves agent under different irradiances from full expansion through senescense. Plant Cell Physiol 33:1209-1214.
Hosang, E. 1991. Pengaruh Waktu Pemangkasan Terhadap Pertumbuhan dan Hasil Jagung (Zea mays. L), Varietas Kalingga. Skripsi Sarjana Pertanian. Fakultas Pertanian Universitas Nusa Cendana Kupang.

Jumin, H. B. 2010. Dasar-dasar Agronomi. Divisi Buku Perguruan Tinggi. PT. Raja Grafindo Persada Jakarta.

Paruntu, J., 1992. Produksi Tanaman dan Beberapa Teknologi Alternatif. Disampaikan dalam seminar Alumni dalam rangka Dies Natalis Fakultas Pertanian Unsrat ke 32. Manado.

Paruntu, J. dan J.L. Pelenewen, 1990. Analisis Tumbuh dan Efisiensi Penggunaan Radiasi Pada Tanaman Jagung. Fakultas Pertanian Unsrat Manado.

Runtunuwu, D.S., 1990, Tumpangsari Jagung dan Kedelai di bawah Naungan Kelapa Tua. Tesis Magister. KPK IPBUNSRAT. Manado.

Salisbury, F.B. dan C.W. Ross, 1995. Fisiologi Tumbuhan, Jilid 3. Penerbit ITB. Bandung. 343 hal.

Sitompul, S.M. dan B. Guritno. 1995. Analisis Pertumbuhan Tanaman. GMU Press. 412 hal.

Sutejo, M.M. 1995. Pupuk dan Cara Pemupukan. Rineka Cipta. Jakarta.

Surbekti, N.A., Syafruddin, R. Effendi, S. Sunarti,. 2012. Morfologi Tana-man dan Fase Pertumbuhan Jagung.Balai Penelitian Tanaman Serealia, Maros. http://balitsereal.litbang.pertanian.go.id /ind/images/stories/empat.pdf. Diakses tgl 12 November 2014.

Surbakti M. F., S. Ginting, dan J. Ginting, 2013. Pertumbuhan Dan Produksi Jagung (Zea mays L.) Var. Pioneer-12 Dengan Pemangkasan Daun Dan Pemberian Pupuk NPKMg. Jurnal Online Agroekoteknologi Vol.1, No.3, Juni 2013 ISSN No. 2337-6597. 